\title{
Utilisation Potentials of Invasive Plants in the Owabi Dam in the Ashanti Region of Ghana
}

\author{
Albert Banunle, ${ }^{\mathrm{a}, *}$ Bernard Fei-Baffoe, ${ }^{\mathrm{a}}$ Kodwo Miezah, ${ }^{\mathrm{a}}$ Nana Ewusi-Mensah, \\ Uffe Jørgensen, ${ }^{\mathrm{c}, \mathrm{g}}$ Robert Aidoo, ${ }^{\mathrm{d}}$ Alice Amoah, ${ }^{\mathrm{b}}$ Robert Clement Abaidoo, ${ }^{\mathrm{e}}$ and \\ Alex Amerh Agbeshie b,f
}

\begin{abstract}
This paper provides a compendium of the utilisation potential of aquatic invasive plants found in the Owabi Dam in the Ashanti Region of Ghana. In total, seven aquatic invasive plants were identified in the Owabi Dam, which included Ceratophyllum demersum, Nymphaea odorata, Polygonum lanigerum, Arthropteris orientalis, Typha domingensis, Pistia stratiotes, and Cyprus papyrus. Some of the identified invasive plants were found to be highly nutritious and suitable for human consumption or use as feed for livestock, fish, and poultry. Other plants had high medicinal potential and aesthetic value. Several of the invasive plants were suitable for bio-industrial usages as feedstock to produce biofuels, insecticides, and biofertilizer, among other products. Therefore, if an effective utilization method of these currently unutilized aquatic invasive plants is established, it can provide a source of livelihood and income generation for individuals and households and contribute to controlling the impact of invasive plants on the Owabi Dam.
\end{abstract}

Keywords: Bioresources; Biofertilizer; Biofuel; Insecticides; Medicine; Aesthetic

Contact information: a: Department of Environmental Science, Kwame Nkrumah University of Science and Technology, Kumasi, Ghana; b: Department of Crop and Soil Sciences, Kwame Nkrumah University of Science and Technology, Kumasi, Ghana; c: Department of Agroecology, Aarhus University, Foulum, Denmark; d: Department of Agricultural Economics, Agribusiness and Extension, Kwame Nkrumah University of Science and Technology, Kumasi, Ghana; e: Office of Grant and Research, Kwame Nkrumah University of Science and Technology, Kumasi, Ghana; f: Department of Environmental Management, University of Energy and Natural Resources, Box 214, Sunyani, Ghana; g: Aarhus University Centre for Circular Bioeconomy; *Corresponding author: asingyea@yahoo.com

\section{INTRODUCTION}

The presence of invasive species in any habitat can threaten species diversity, the environment, economic development, and public health. Invasive plants include exotic species that persist in a new environment, reproduce, and spread greatly in distribution (Havel et al. 2015). Native species that colonize a site rapidly and eliminate the chance for plant biodiversity are also considered invasive plants (Leger and Espeland 2010). Due to their nature, invasive species have the potential to multiply rapidly and take over any bioregion into which they are introduced (Tobin 2018). Invasive plants, for instance, have been found to colonize large areas of terrestrial and aquatic ecosystems, which causes remarkable economic and ecological losses in a short period (Thomaz et al. 2015). In aquatic environments, the presence of invasive plants affects the quality and quantity of the water (Smith and Knapp 2011), disrupts ecological processes (Van Wilgen 2017), and increases the cost of treating water for domestic use (Turpie 2004). Invasive plants affect 
water quality and aquatic ecosystem health by altering the ecological stability of riverbanks and the volume and pollution levels in runoff (McCormick et al. 2009).

Theoretically, invasive plants are mostly dispersed into new habitats via natural migration, floods, storms, and other events (Eminniyaz et al. 2013). However, in some cases, humans may transport invasive plant species into aquatic bodies deliberately or accidentally. Indeed, anthropogenic activities have been recognized as a key pathway for the introduction of invasive plants into most water bodies (Tobin 2018). Agricultural activities and waste disposal are a remarkable anthropogenic source of invasive species in water bodies; they are an especially prevalent source in developing countries, where a large quantity of fresh untreated wastes from households and farm sources find their way into water bodies (Manfredi et al. 2010). In small quantities, invasive plants in water pose little threat. However, in large quantities, invasive plants become a serious nuisance, and they are injurious and problematic for users and managers of water resources.

Due to the known impacts of invasive plants in water, water resource managers are often concerned with the presence of any patch of invasive plants in their water system, and they employ various means in controlling their spread. The literature has shown that many of the conventional invasive plant control methods and techniques require immense capital and human resources with little or no noticeable success (Wong et al. 2017). However, recent advances in bioeconomic technology have made it possible to envision a new strategy to manage invasive plant species in water bodies by converting them into value-added products, such as compost, biochar, medicine, and biofuels, among others (Borokini and Babalola 2012). Invasive plant species have large potential for bio-resource exploitation due to their relatively high photosynthetic efficiency, fast growth, high carbohydrate content, lack of required cultivation land area, and lack of competition with food crops (Stratton and Goldstein 2001). The traditional usage of some invasive plants for cultural and aesthetic purposes has been documented, which provides an additional pathway for the removal and utilisation of aquatic invasive plants.

Despite the high resource potential of aquatic invasive plants and the prospects of their exploitation for socioeconomic benefits, such as livelihood improvement, income generation, and local economic development, limited knowledge and awareness regarding their beneficial uses are obstacles to their effective utilization. In the Owabi Dam located in the Atwima Nwabiagya District in the Ashanti Region of Ghana, different invasive plant species exist, but there is limited or no documented evidence on their benefits. However, as indiscriminate waste disposal and agrarian activities around the Owabi Dam continue, the growth and spread of invasive plants will create problems for the Ghana Water Company Limited's (GWCL) processing of the water from the dam for domestic use. This paper aims to identify and provide a comprehensive review of the utilisation potential of the available aquatic invasive plants in the Owabi Dam.

\section{EXPERIMENTAL}

\section{Study Area (Owabi Dam)}

This study was conducted at the Owabi Dam located in the Atwima Nwabiagya Northern District in the Ashanti Region of Ghana. The Owabi Dam is located at latitude $06-43^{\circ} \mathrm{N}$ and longitude $01-36^{\circ} \mathrm{W}$ with an altitude of $287 \mathrm{~m}$. It is near the Akropong Esaase in the Atwima Mponua District of the Ashanti region of Ghana, and it was constructed in 1928 (Tetteh et al. 2004). The Owabi River comes together with seven tributaries to form 
the reservoir. The average area of the entire reservoir is $3.5 \mathrm{~km}^{2}$ with an average depth of $6.9 \mathrm{~m}$. The dam (reservoir) is a protected area under the management of the Ghana Water Company Limited (GWCL). The study focused on the dam itself and the marshland surrounding it where invasive plants are found.

\section{Identification of invasive plants}

An ecological survey was conducted throughout the Owabi Dam, and transect movement was performed to identify and take samples of different aquatic invasive plant species in the dam. All the identified aquatic invasive plants were harvested manually from the dam. The harvested plants were sorted into their respective species with the assistance of a skilled botanist. Then, they were washed to remove dust particles and packed into polythene bags. The plants were transported to the Botany Laboratory at the Department of Theoretical and Applied Biology of the Kwame Nkrumah University of Science and Technology (KNUST) (Kumasi, Ghana) for confirmatory identification. After each species was identified, the International Union for Conservation of Nature (IUCN) Global Invasive Species Database (GISD) (IUCN Invasive Species Specialist Group (ISSG) 2006) was consulted to confirm the invasive status of each species.

\section{Bibliometric Review}

Bibliometric studies of each of the different invasive plants in the Owabi Dam were conducted. The first step consisted of searching for all known beneficial and socioeconomic uses of aquatic invasive plants published in journals and available from open-access electronic databases and search engines, which included Science Direct, Emerald, Sage, and Google Scholar. Phrases such as "beneficial uses," "economic value," "sociocultural/socioeconomic value," "utilization," "exploitation," "medicinal use," and their synonyms were searched with the names of invasive plants across different databases. After identifying all known beneficial and socioeconomic uses of aquatic invasive plants, the benefits were grouped into three thematic areas viz, medicinal uses, bioeconomic uses, and cultural and aesthetic uses. A further search was then conducted using the identified invasive plants to find studies that have documented the usage of the identified aquatic invasive plants under each of the three thematic areas.

\section{RESULTS AND DISCUSSION}

\section{Invasive Plants in the Owabi Dam}

From the ecological survey at the Owabi Dam, seven aquatic invasive plant species were identified, namely Ceratophyllum demersum, Nymphaea odorata, Polygonum lanigerum, Arthropteris orientalis, Typha domingensis, Pistia stratiotes, and Cyperus papyrus. Brief botanical descriptions of each of the identified aquatic invasive plants are as follows:

Ceratophyllum demersum (hornwort, rigid hornwort, coontail, or coon's tail): $C$. demersum (Fig. 1) belong to the family Ceratophyllaceae and is a submerged, cosmopolitan, free-floating aquatic plant that has perennial macrophytes without any roots. It is monoecious, pollinated by water, and known to grow fast in shallow, muddy, quiescent water bodies at low light intensities. The plant is found in ponds, lakes, and rivers with temperatures of $15{ }^{\circ} \mathrm{C}$ to $30{ }^{\circ} \mathrm{C}$ and a rich nutrient status (USDA PLANTS 2011). C. demersum has allelopathic qualities that inhibit the growth of phytoplankton and 
cyanobacteria (blue-green algae). Its most notable negative consequences have occurred in New Zealand, where it has caused problems with hydroelectric power plants (NIWA 2005). C. demersum is native to all continents except Antarctica, it is declared a weed under the Tasmanian Weed Management Act (1999) in Tasmania, Australia, and classed as an unwanted organism in New Zealand (Ministry of Primary Industry (MPI) Biosecurity New Zealand 2012; Global Invasive Species Database 2020).

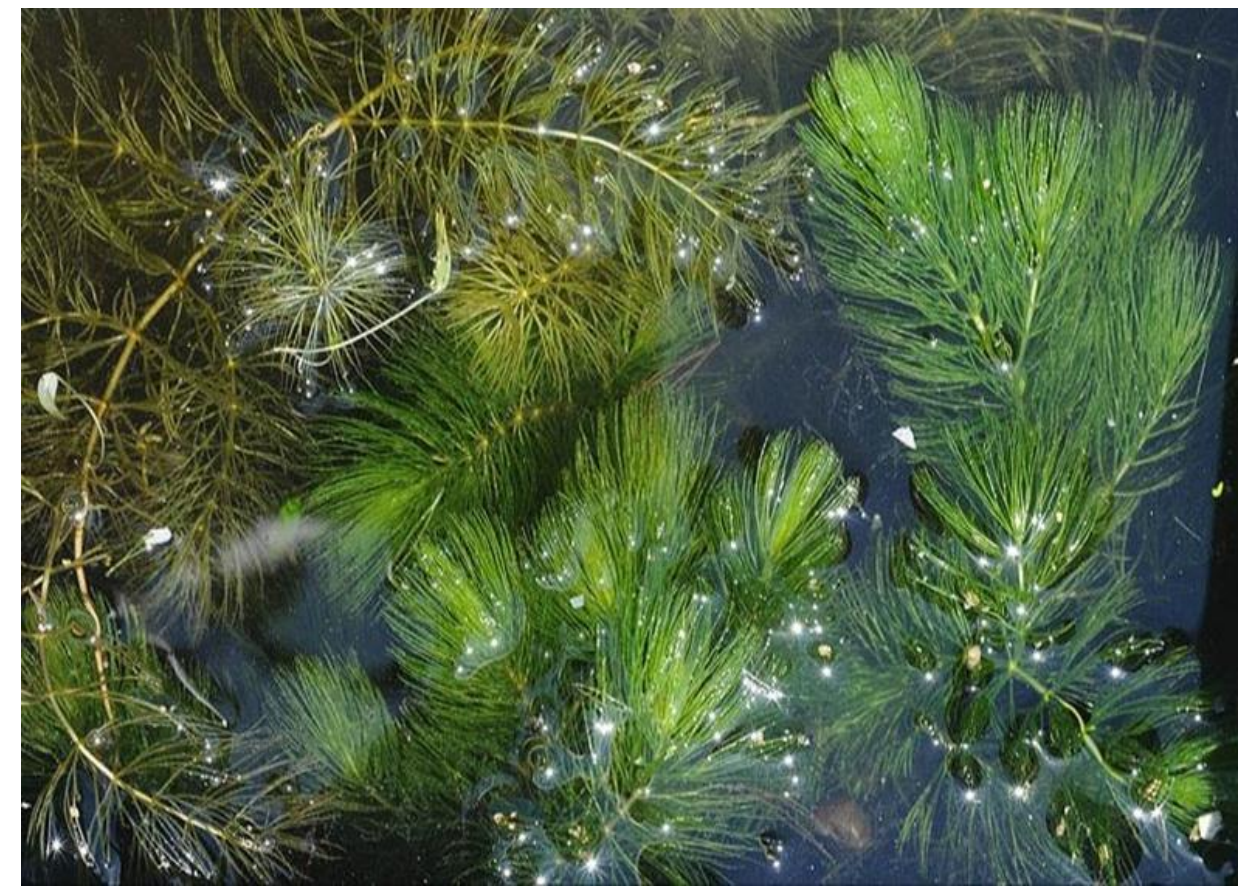

Fig. 1. Ceratophyllum demersum

Nymphaea odorata (water lily): $N$. odorata is an aquatic plant that belongs to the family Nymphaeaceae. The $N$. odorata plant (Fig. 2.) is rooted from a branched rhizome that gives rise to its long petioles that terminate in a smooth, floating, round leaf with a waxy, water-repellent upper coating. The flowers of $N$. odorata also float and are radially symmetric with prominent yellow stamens and many white petals. The flowers open each day, close each night, and are very fragrant.

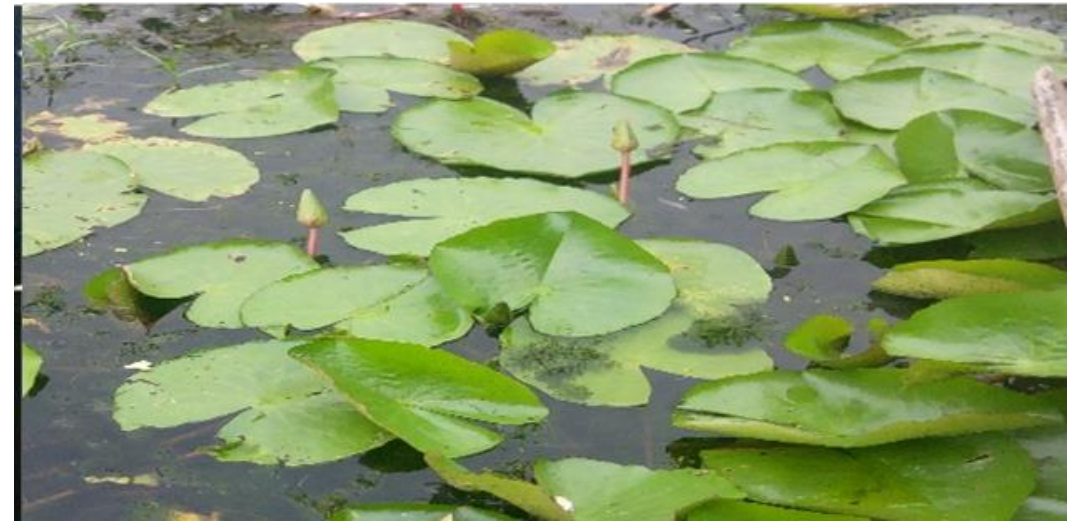

Fig. 2. Nymphaea odorata 
Once the flowers are pollinated, the developing fruit is pulled back underwater for maturation. It has a cosmopolitan distribution and is common in shallow lakes, ponds, and permanent slow-moving waters, and it has been declared an invasive weed (Northey 2014). N. odorata is featured in the databases of the Center for Aquatic and Invasive Plants of the University of Florida (2018) as an aquatic invasive plant native to Florida (Langeland et al. 2006). It can be found commonly throughout North America, where it ranges from Central America to northern Canada, and its presence has also been reported in Brazil and Guyana (Stevens et al. 2001).

Polygonum lanigerum (knotweed): P. lanigerum is a perennial herbaceous plant that is rarely shrubby and has many branched stems. The leaves of P. lanigerum (Fig. 3) are arranged alternately, and they are usually less than $2 \mathrm{~cm}(0.8 \mathrm{in})$ long with a length greater than the width. They have a membranous ochrea (a sheath around the stem nodes). The flowers are usually bisexual, rarely unisexual, and have five tepals, the outer of which is slightly different from the inner ones. There are usually four to six stamens and three styles, though there are two styles in some rare situations. P. lanigerum belongs to the family Polygonaceae, and the produced fruit is three-sided (Ortiz et al. 2008). P. lanigerum has a cosmopolitan distribution, particularly in the temperate regions (Maha et al. 2014), and it has been declared a weedy and invasive aquatic plant in the USA (Cusick and Ortt 1987).

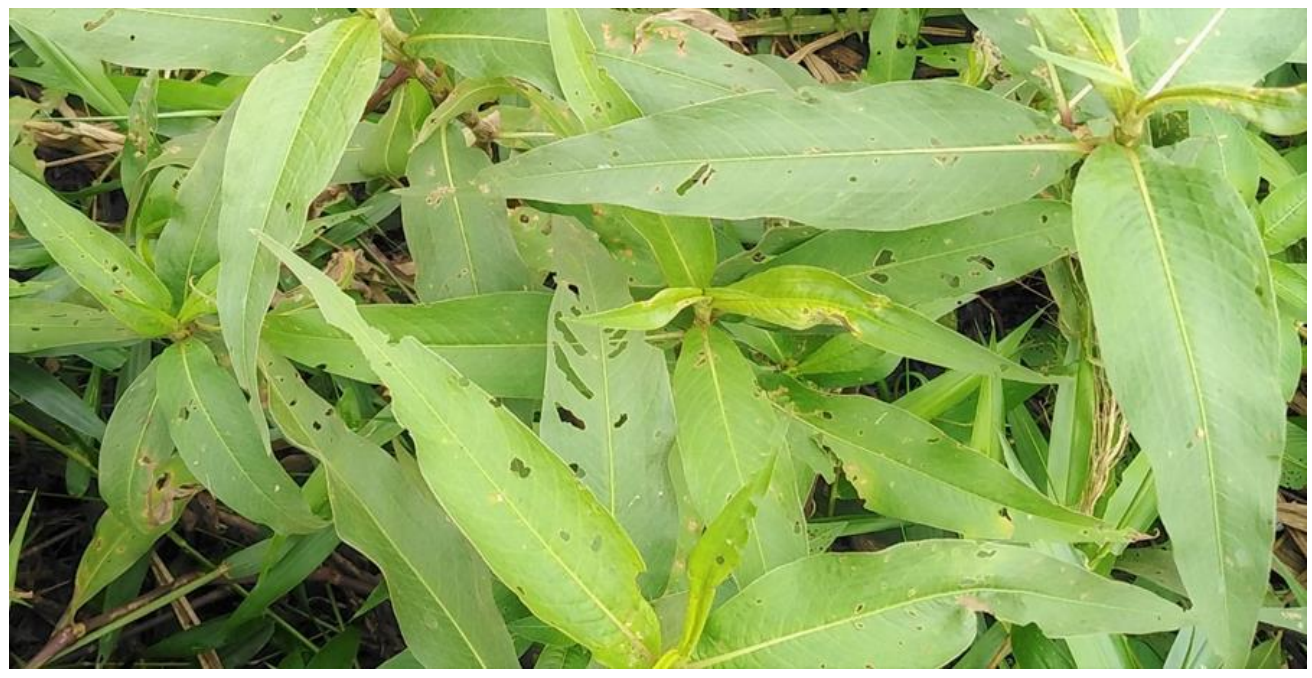

Fig. 3. Polygonum lanigerum

Arthropteris orientalis (Msasa fern): A. orientalis, locally known as Msasa fern, belongs to a small genus of ferns in the family Tectariaceae. It is a creepy plant that has rhizomes up to $3 \mathrm{~mm}$ in diameter with broad scales that are ovate to circular in outline and are up to $1.5 \mathrm{~mm}$ long and dark brown. A. orientalis (Fig. 4) was thought to have originated from the East (Australia) and was therefore named accordingly. It is usually found in rocky areas in open deciduous woodland in dappled shade and seasonally wet grassland with scattered trees. A. orientalis is widely distributed in Australia, Europe, Asia and Africa, and they are particularly numerous in Yemen, Réunion, Madagascar, and Mauritius (Robinson 1991). The Arthropteris orientalis is a species of the family Tectariaceae that is an invasive weed; these plants can establish themselves well in disturbed habitats (Perrings et al. 2005), and they are mostly found in disturbed areas, such as farms, impoundments, and settlement areas. 


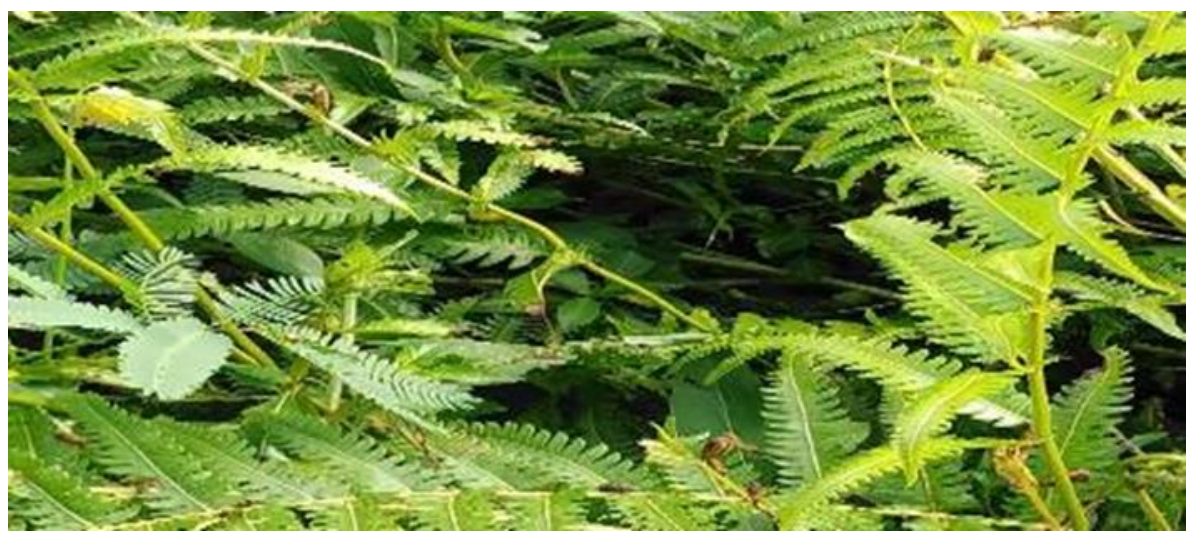

Fig. 4. Arthropteris orientalis

Typha domingensis (Cattail): T. domingensis is an aquatic plant from the family Typhaceae. It is a perennial monoecious plant that grows up to $3 \mathrm{~m} \mathrm{(9} \mathrm{ft} 10 \mathrm{in}$ ) and is pollinated by wind. It prefers wet soil and can grow in soil characterized as saline, acid, neutral, and basic. In addition, it can grow in water. $T$. domingensis requires a rich wet soil to do well. It can grow in sun or partial shade and is highly invasive, spreading freely at the roots when in contact with a suitable medium. T. domingensis aggressively invades and forms nearly pure stands in brackish to fresh marshes and pools common in North America, where it is believed to have originated (Fig. 5). T. domingensis is widespread in the tropics, subtropics, and warm temperate regions. It has been found in some African countries, including Ghana, Ethiopia, Guinea, and Zambia. In addition, it has been found in Central America, North America, South America, Asia, and Australia.

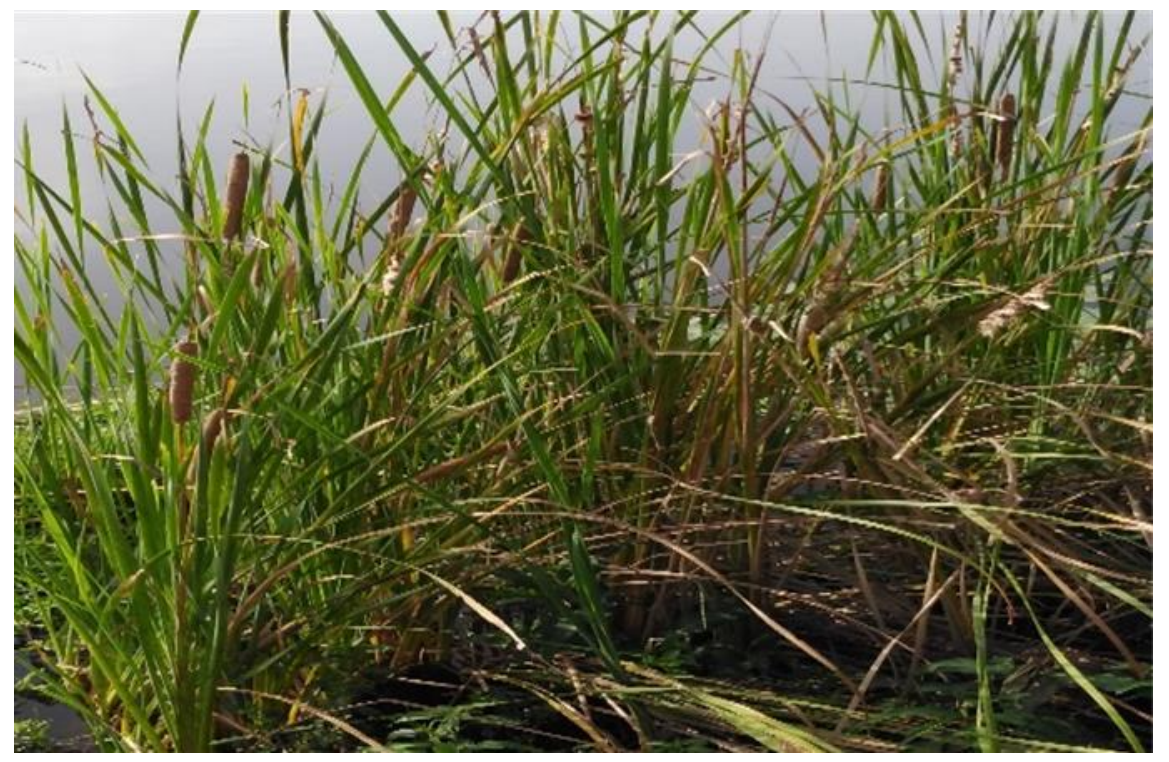

Fig. 5. Typha domingensis

Pistia stratiotes (water lettuce, water cabbage, Nile cabbage, or shellflower): $P$. stratiotes is a floating, stoloniferous herbaceous plant that grows in ponds and streams. It has green, odourless, and bitter leaves. The leaves (Fig. 6) are approximately $13 \mathrm{~cm}$ long 
and $17 \mathrm{~cm}$ wide, they are fan-shaped and have parallel venation, blunt apex, and have entire margin (i.e. margin without serrations). It belongs to the family Araceae with an uncertain native distribution, but it is probably pantropical, as it was first discovered from the Nile near Lake Victoria in Africa. Through human introduction, $P$. stratiotes is now appearing in nearly all fresh waterways in the tropics and sub-tropics. It is a productive freshwater aquatic plant and is considered an invasive species (Muniappan et al. 2009). In waters with high nutrient content, especially those particularly contaminated with sewage or fertilizers from human activities, water lettuce can often exhibit weedy overgrowth behavior; therefore, it is a common weedy plant in hydrologically altered systems, such as canals and reservoirs (Kasulo 2000).

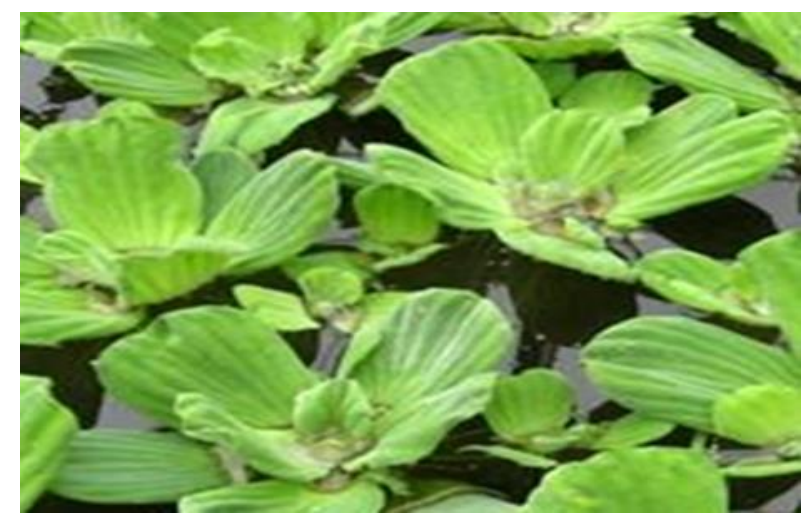

Fig. 6. Pistia stratiotes

Cyprus papyrus (Papyrus sedge, Nile grass): C. papyrus is a species of aquatic flowering plant that belongs to the sedge family (Cyperaceae). It is a tender herbaceous perennial native to Africa, and it forms tall stands of reed-like swamp vegetation in shallow water.

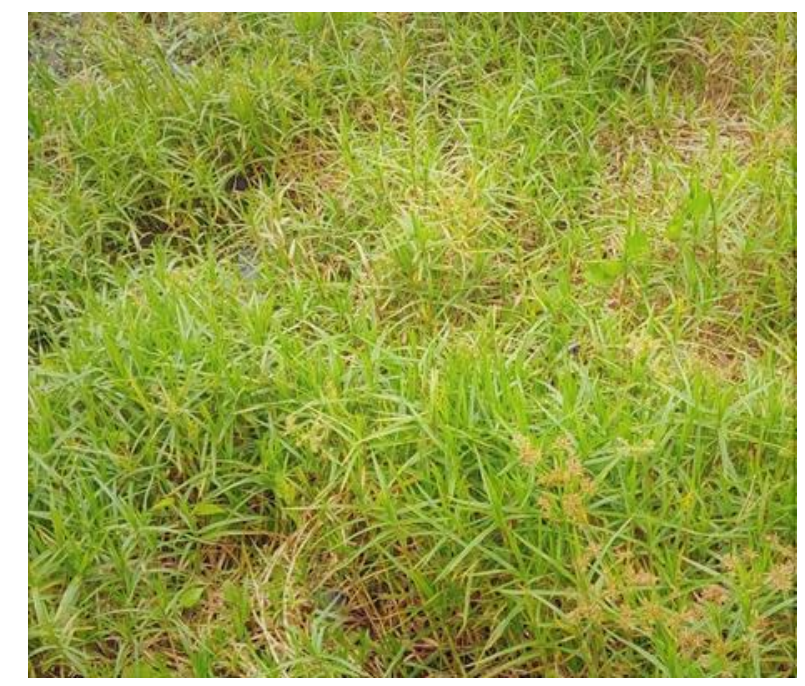

Fig. 7. Cyperus papyrus

As an aquatic plant, C. papyrus is robust, leafless, and can grow $4 \mathrm{~m}$ to $5 \mathrm{~m}$ high. It usually forms grass-like clumps of triangular green stems that rise from its thick, woody rhizomes. Each stem of $C$. papyrus (Fig. 7) is topped by a dense cluster of thin, bright 
green, thread-like stems of $10 \mathrm{~cm}$ to $30 \mathrm{~cm}$ in length. C. papyrus is a fast-growing perennial sedge native to central Africa and the Nile Valley, and has been introduced, often as an ornamental species, to other warm parts of the world.

According to the Centre for Agriculture and Bioscience International (CABI) (2004), C. papyrus is an invasive plant that is a serious threat to ecosystems and impedes the flow of waterways. $C$. papyrus is highly invasive within and outside its native range, highly mobile locally, fast growing, and highly reproductive. In Ghana, C. papyrus is reported as an introduced species (CABI, 2004; Ernest 2015) and has been found in places such as Kpong Headpond, Silicon Hotel, Kumasi, and Accra.

\section{Potentially Beneficial Values of Aquatic Invasive Plants in the Owabi Dam}

From a review of literature on the identified aquatic invasive plants in the Owabi Dam, their utilisation potentials were identified and outlined under three themes: medicinal potency, bioeconomic usage, and cultural and aesthetic usage.

\section{Medicinal Potency}

Historically, invasive plants are known to have medicinal properties and hence have been used for the treatment of various ailments. The suitability of invasive plants for medicinal use is supported by their phytochemical constituents and biologically active chemical or natural products, such as alkaloids, glycosides, flavonoids, terpenoids, tannins, and steroids (Rashmi and Rajkumar 2011). From the review presented in Table 1, almost all the identified invasive plants (i.e., C. demersum, $N$. odorata, P. lanigerum, A. orientalis, $T$. domingensis, and $P$. stratiotes) have reported analgesic and antimicrobial uses. Many invasive plants have a noticeable amount of aspirin, morphine, codeine, and thebaine (paramorphine), which gives them high analgesic potency and curative uses. Some of the aquatic invasive plants, especially $C$. demersum, have allelopathic compounds to defend against feeding (NIWA 2005). Many of the allelopathic compounds produced by invasive plants tend to be effective in the treatment of infections and ailments, thereby improving the medicinal uses and curative potential of invasive plants.

Aside from the analgesic uses of invasive plants, the results in Table 1 show that invasive plants are also used as antimicrobials (Kakarla et al. 2014), anti-inflammatory medicine (Karale et al. 2013; Syed et al. 2018), diuretics (Bansal et al. 2019), tonics (Jain 2017), antimalarial drugs (Oladimeji et al. 2008; Ma et al. 2019), and antidermatophytic medication (Premkumar and Shyamsundar 2005), among others. Before the scientific exploitation of invasive plants for their phytochemical constituents as medicine, local knowledge was available on the usage of some invasive plants for medicinal purposes. Abu (2015), Karataş et al. (2014), and Taranhalli et al. (2011) all presented evidence of local uses of invasive plants, such as $C$. demersum for the treatment of wounds, fever, burning sensation, and piles, among others. The leaves of $T$. domingensis have also been used as a diuretic in Chinese medicine (Duke and Ayensu 1985), and nose bleeds, hematemesis, hematuria, uterine bleeding, dysmenorrhea, and postpartum abdominal pain were also treated with the pollen of $T$. domingensis (Yeung 1995). Seeds and rootstock of the $T$. domingensis have also been used in treating haemostatic conditions in human (Duke and Ayensu 1985) and as a diuretic (Chopra et al. 1986).

In addition, Pistia stratiotes is used as "Tridosha," which is a treatment for fever and diseases of the blood. The leaves of $P$. stratiotes have been used for curing kidney afflictions, hematuria, dysentery, and anemia, among other issues (Tripathi et al. 2010). C. demersum also has local medicinal uses in Chinese medicine for cooling, antiperiodic, 
treatment of biliousness, and scorpion stings (Yeung 1995). It emerged from the study that curative/medicinal uses of invasive plants are most common in China, India, Bangladesh, Australia, and many North American countries, whereas they are still obscure in Africa. The disparity in medicinal usage of invasive plants globally is due to disproportionate knowledge and awareness of the curative properties and the techniques for converting invasive plants into finished products for use as medicines.

Table 1. Medicinal Uses of Invasive Plants Identified in the Owabi Dam

\begin{tabular}{|c|c|c|}
\hline Invasive Plants & Medicinal Uses & References \\
\hline \multirow[t]{7}{*}{$\begin{array}{l}\text { Ceratophyllum } \\
\text { demersum }\end{array}$} & Analgesic & $\begin{array}{l}\text { Karale et al. (2013); Malathy and } \\
\text { Stanley (2015); Syed et al. (2018) }\end{array}$ \\
\hline & Antimicrobial & Fareed et al. (2008) \\
\hline & Anti-inflammatory & $\begin{array}{c}\text { Karale et al. (2013); Syed et al. } \\
\text { (2018) }\end{array}$ \\
\hline & Cooling agent & Khare (2004) \\
\hline & Diuretic & Zhang et al. (2013) \\
\hline & Wound healing, fever, pills & $\begin{array}{c}\text { Taranhalli et al. (2011); Karataş et al. } \\
\text { (2014) }\end{array}$ \\
\hline & Tonic (cardio-tonics) & Syed et al. (2018) \\
\hline \multirow[t]{7}{*}{ Nymphaea odorata } & Analgesic & Selvakumari et al. (2016) \\
\hline & Antimicrobial & Oladimeji et al. (2008) \\
\hline & Antimalarial & Oladimeji et al. (2008) \\
\hline & Tonic & Singh and Jain (2017) \\
\hline & Narcotics & Emboden (1981) \\
\hline & Diuretic & Selvakumari et al. (2016) \\
\hline & Aphrodisiac & Selvakumari et al. (2016) \\
\hline \multirow{3}{*}{$\begin{array}{l}\text { Polygonum } \\
\text { lanigerum }\end{array}$} & Analgesic & Saha et al. (2005) \\
\hline & Anti-inflammatory & Saha et al. (2005) \\
\hline & Diuretic & Saha et al. (2005) \\
\hline $\begin{array}{c}\text { Arthropteris } \\
\text { orientalis }\end{array}$ & Analgesic & Syed et al. (2018) \\
\hline \multirow{4}{*}{ Typha domingensis } & Analgesic & Islam et al. (2015) \\
\hline & Nose bleeds, dysmenorrhoea & Yeung (1995) \\
\hline & $\begin{array}{l}\text { Haemostatic conditions } \\
\text { (bleeding) }\end{array}$ & Duke and Ayensu (1985) \\
\hline & Diuretic & Bansal et al. (2019) \\
\hline \multirow[t]{4}{*}{ Pistia stratiotes } & Analgesic & Kumar et al. (2011) \\
\hline & Antimalarial (larvacides) & Ma et al. (2019) \\
\hline & Antidermatophytic & $\begin{array}{l}\text { Premkumar and Shyamsundar } \\
(2005)\end{array}$ \\
\hline & $\begin{array}{l}\text { Treating ulcer, leprosy, and } \\
\text { eczema }\end{array}$ & Khan et al. (2014) \\
\hline Cyperus papyrus & Antimicrobial uses & Kakarla et al. (2014) \\
\hline
\end{tabular}

In Africa, few cases of aquatic invasive plants used for medicinal purposes have been reported. In Southern Africa, Maema et al. (2016) reported the use of some invasive plants, such as Schinus molle (L.) and Catharanthus roseus (L.), by communities to treat various ailments in humans. The use of the identified invasive plants in the Owabi Dam (C. demersum, $N$. odorata, $P$. lanigerum, A. orientalis, $T$. domingensis, $P$. stratiotes, and C. papyrus) for medicinal purposes is not common, despite their abundance. Among the invasive plants identified, only those of the family Cyperaceae (C. papyrus) have known 
medicinal uses in Ghana (Boadu and Asase 2017). As such, the many other invasive plants with potent medicinal properties have not yet been discovered in Ghana.

\section{Bioeconomic Usage}

Many invasive plants have demonstrable potential as feedstocks to produce valueadded biobased items, materials, and services. Chemical, mechanical, and biological transformation of the biomass of invasive plants into various useful products of economic importance have been reported. The identified bioeconomic uses of invasive plants as summarized in Table 2 show that invasive plants have been used in biogas, biodiesel, and bioethanol production (Pastare et al. 2015; Kaur et al. 2018; Kusolsongtawee et al. 2018). In addition, they have been used in the production of botanical insecticides (Dogan et al. 2017; Koranteng et al. 2018), biofertilizer, compost, and potash (Aboohanah and Yeaser 2018). Further, invasive plants have been used to produce paper and related products (Leach and Tait 2000), among others. The various bioeconomic uses identified indicate that invasive plant valorization is a potential source of income. A study by Tardivel (2018) observed that, in the Pacific Island Countries and Territories, valorization of several invasive species has provided much economic opportunity for households and communities.

Table 2 also shows the usage of invasive plants for phytoremediation and heavy metal removal (Essuman 2013), biological life support (Voeste et al. 2003), and wastewater purification (Foroughi et al. 2010; Mburu et al. 2015; Rusnam 2016). These studies, among others, have demonstrated the enormous potential of the bioeconomic usage of the identified invasive plants globally. According to Tardivel (2018), market incentives for invasive plant control is currently gaining attention globally as a result of the realization of the enormous potential of invasive plants as feedstock for biobased product development. Many invasive plants that were considered nuisances are now recognized as valuable bioresources (Van Meerbeek et al. 2015).

Several industrial and agro-industrial applications of invasive plants have been reported, which demonstrate their high bioeconomic value. Invasive plants have been utilized as a feedstock to produce compost (Kanwal et al. 2011), biochar (Liu et al. 2019), potash/manure (Polthanee et al. 2015), and other bio-based products that have high agrarian and industrial relevance. Two of the aquatic invasive plants identified in the Owabi Dam (P. stratiotes and C. demersum) have been previously used as feedstocks for compost production (Kanwal et al. 2011; Aboohanah and Yeaser 2018), and nearly all have demonstrable success as feed for livestock, poultry, and fish production (Huxley and Griffiths 1992; Atala 2012; Ekunseitan et al. 2013; Essuman 2013; Mohammed et al. 2015).

Many invasive plants have high nutrient content, which includes crude fibre, lipids, protein, and carbohydrates; therefore, they are suitable for human consumption, use as feed, and use as a feedstock for conversion into valuable bio-based products (Stephen et al. 2017). The seeds of $T$. domingensis, for instance, contain high linoleic acid and are therefore used to feed cattle and chickens (Reed and Marsh 1955). Three of the aquatic invasive plants found in the Owabi Dam (N. odorata, P. lanigerum, and T. domingensis) are reportedly used for human consumption in Turkey and other places (Lim 2016; Stephen et al. 2017; Kayabaş et al. 2018). These observations demonstrate that invasive plants can be used both as feed for animals and human consumption. According to Huth et al. (2018), the consumptive potential of many invasive species is high, and they are more market competitive due to their "environmentally friendly" nature. 
Table 2. Bioeconomic Usage of Invasive Plants Identified in the Owabi Dam

\begin{tabular}{|c|c|c|}
\hline Invasive Plants & Bioeconomic Uses & References \\
\hline \multirow[t]{10}{*}{$\begin{array}{l}\text { Ceratophyllum } \\
\text { demersum }\end{array}$} & Remediation of dumpsites & $\begin{array}{c}\text { Stilinovic and Hrenovic } \\
(2000)\end{array}$ \\
\hline & Biological life support & Voeste et al. (2003) \\
\hline & Heavy metal adsorption & Keskinkan et al. (2004) \\
\hline & Bioethanol production & Kusolsongtawee et al. (2018) \\
\hline & Water/sewage purification & Foroughi et al. (2010) \\
\hline & Biomethane/biogas/bioenergy & $\begin{array}{c}\text { Pastare et al. (2015); Kaur et } \\
\text { al. (2018) }\end{array}$ \\
\hline & Biofertilizer (liquid fertilizer) & $\begin{array}{c}\text { Aboohanah and Yeaser } \\
(2018)\end{array}$ \\
\hline & Pesticide and botanical insecticides & Koranteng et al. (2018) \\
\hline & Biochar production & Liu et al. (2019) \\
\hline & Bioindicator for heavy metals & Polechońska et al. (2018) \\
\hline \multirow{4}{*}{$\begin{array}{l}\text { Nymphaea } \\
\text { odorata }\end{array}$} & Wastewater purification & Rusnam (2016) \\
\hline & Bio-indicator of water quality & Polechońska et al. (2018) \\
\hline & Food crop (young leaf) & Stephen et al. (2017) \\
\hline & Fish feed & Mohammed et al. (2015) \\
\hline \multirow[t]{3}{*}{$\begin{array}{l}\text { Polygonum } \\
\text { lanigerum }\end{array}$} & Eaten in parts of central Turkey & $\begin{array}{c}\text { Łuczaj (2008); Kayabaş et al. } \\
\text { (2018) }\end{array}$ \\
\hline & $\begin{array}{l}\text { Used as anti-feedant and } \\
\text { insecticide }\end{array}$ & $\begin{array}{c}\text { Quesada-Romero et al. } \\
(2017)\end{array}$ \\
\hline & Fodder/animal feed & Ekunseitan et al. (2013) \\
\hline \multirow{2}{*}{$\begin{array}{l}\text { Arthropteris } \\
\text { orientalis }\end{array}$} & Phytoremediation of heavy metals & Essuman (2013) \\
\hline & Animal feed/fodder & Essuman (2013) \\
\hline \multirow{4}{*}{$\begin{array}{c}\text { Typha } \\
\text { domingensis }\end{array}$} & Bioethanol production & Grosshans (2014) \\
\hline & Edible to humans & $\operatorname{Lim}(2016)$ \\
\hline & Paper production & Colbers et al. (2017) \\
\hline & Diapers, baby powder, and cradleboards & $\begin{array}{c}\text { Jahan et al. (2007); Bidin et } \\
\text { al. (2015) }\end{array}$ \\
\hline \multirow[t]{6}{*}{ Pistia stratiotes } & Biogas production & $\begin{array}{c}\text { Nipaney and Panholzer } \\
\text { (1987) }\end{array}$ \\
\hline & Eaten in soup preparation & Ruffo et al. (2002) \\
\hline & Used as insecticides & Ito et al. (2015) \\
\hline & Cover for spawning fish in fish farming & Huxley and Griffiths (1992) \\
\hline & Manure (potash) & Polthanee et al. (2015) \\
\hline & Feedstock for compost & Kanwal et al. (2011) \\
\hline \multirow[t]{6}{*}{ Cyperus papyrus } & Production of bioethanol & $\operatorname{Lim}(2016)$ \\
\hline & Biomass briquette production (biofuel) & $\begin{array}{c}\text { Morrison et al. (2014); Jones } \\
\text { et al. (2018) }\end{array}$ \\
\hline & Wastewater purification & Mburu et al. (2015) \\
\hline & Phytoremediation of heavy metals & $\begin{array}{c}\text { Jomjun et al. (2010); Mburu } \\
\text { et al. (2015) }\end{array}$ \\
\hline & Usage in the production of paper & Leach and Tait (2000) \\
\hline & Food and feed/fodder for animal & Atala (2012) \\
\hline
\end{tabular}

Although valorization of invasive plants is not entirely new, the recent appeal and interest in circular economy approaches and sustainable production in line with the United Nations Sustainable development goals (SDGs) (UN General Assembly 2015) have resulted in the increasing emergence of technologies and strategies that promote bio-based product development from invasive plants and other materials. Tardivel (2018) noted that 
native or endemic species are increasingly threatened by human economic activities, and as such, invasive alien species with similar potentials are now exploited for their bioeconomic and market potential. In addition, there is interest in scientific discovery of the suitability and potential of various invasive plants for bioeconomic exploitation. For instance, $T$. domingensis is a well-known bioenergy crop used as a source of starch to produce ethanol (Dubbe et al. 1988). Moerman (2010) also reported the use of $T$. domingensis as an alternative to cotton and linen in the clothing industry. Based on these findings, it can be inferred that the invasive plants found in the Owabi Dam have high bioeconomic resource potential, although reports on local usage is still obscure, and quantification of the potential is still lacking.

\section{Cultural and Aesthetic Usage}

Beyond the medicinal and bioeconomic usage of invasive plants, there is abundant evidence indicating their cultural and aesthetic values. As presented in Table 3, this includes usage as cultural symbols, ornamental pot plants, architectural motifs, and decorations.

Table 3. Cultural and Aesthetic Usage of Aquatic Invasive Plants Identified in the Owabi Dam

\begin{tabular}{|c|c|c|}
\hline Invasive Plants & Cultural and Aesthetic Uses & References \\
\hline Ceratophyllum demersum & Aquarium plants & Syed et al. 2018 \\
\hline \multirow[t]{5}{*}{ Nymphaea odorata } & Ornamentals plants & Stephen et al. (2017) \\
\hline & $\begin{array}{c}\text { Symbols of fertility } \\
\text { gods/goddess (ancient Egypt) }\end{array}$ & Tresidder (1997) \\
\hline & $\begin{array}{c}\text { National flower of Sri Lanka and } \\
\text { Bangladesh }\end{array}$ & Jayasuriya (2011) \\
\hline & $\begin{array}{c}\text { Architectural motifs and } \\
\text { decorations }\end{array}$ & Tresidder (1997) \\
\hline & $\begin{array}{c}\text { Decorative container storage } \\
\text { containers }\end{array}$ & Comedis et al. (2017) \\
\hline Polygonum lanigerum & - & - \\
\hline Arthropteris orientalis & Ornamental plants & $\begin{array}{c}\text { Aboohanah and Yeaser } \\
\text { (2018); Addo-Fordjour et al. } \\
\text { (2007) }\end{array}$ \\
\hline \multirow[t]{3}{*}{ Typha domingensis } & Thermal insulation in buildings & Colbers et al. (2017) \\
\hline & Tinder for starting fires & Moerman (2010) \\
\hline & $\begin{array}{l}\text { Stuffing material for pillows, } \\
\text { mattresses, and toys }\end{array}$ & $\begin{array}{c}\text { McPherson and McPherson } \\
\text { (1977) }\end{array}$ \\
\hline Pistia stratiotes & $\begin{array}{c}\text { Ornamental plants in water } \\
\text { gardens }\end{array}$ & Chapman et al. (2017) \\
\hline \multirow[t]{2}{*}{ Cyperus papyrus } & Ornamental or pot plants & Atala (2012) \\
\hline & $\begin{array}{l}\text { Making mats, fences, hats, and } \\
\text { botanical beads }\end{array}$ & Atala (2012) \\
\hline
\end{tabular}

Tresidder (1997) reported that in ancient Egypt, $N$. odorata was used as a lotus motif and to symbolize fertility gods and goddesses. The flower of $N$. odorata is also the national flower of Sri Lanka and Bangladesh (Jayasuriya 2011). Thus, in these countries, $N$. odorata is a plant of cultural importance. 
In some communities, invasive plants, such as $C$. papyrus, are used in handcraftsmanship for making mats, fences, hats, and botanical beads (Atala 2012). According to Dos Santos et al. (2014), invasive plants within the semi-arid area of northeastern Brazil are culturally important, as they are used in local craftsmanship for constructing houses, hats, and beds, among other things. For local native tribes around Lake Titicaca in Peru and Bolivia, T. domingensis is a valuable plant for cultural activities, which include its use for the thermal insulation of local buildings (Colbers et al. 2017) and making storage containers (Comedis et al. 2017), mats, fences, hats, and botanical beads (Atala 2012). The aesthetic and cultural value of invasive plants constitute additional competitive beneficial uses.

\section{Management Issues}

While the findings show that the identified invasive plants have various utilisation potentials, a number of management issues need to be addressed to ensure efficient harnessing of them for the various benefits. To prevent a situation whereby local indigene may propagate the invasive plants elsewhere due to their economic benefits, public education on the negative impacts of the invasive plants on water resources and farmlands should be carried out. The local district assembly together with local authorities can also be persuaded to enact byelaws that prohibit deliberate propagation of invasive plants in the district. To address occupational health risk that may be associated with harvesting of the invasive plants by the local inhabitants also, only the trained "water workers" at the Owabi dam should be allowed to undertake harvesting for anyone that intent to utilize any invasive plant in the dam. For any reason if local inhabitants should engage in harvesting of the invasive plants in the Owabi dam, this should be proceeded by effective and use of the necessary personal protection equipment (PPE).

\section{CONCLUSIONS}

1. The environmental, economic, and health impacts of aquatic invasive plants have been widely reported in many studies.

2. Competitive beneficial uses of various invasive plants species based on local knowledge and emerging bio-based technology have also been found.

3. The findings make clear that the invasive plants have medicinal uses, bioeconomic potential, and cultural and aesthetic values.

4. If appropriately harnessed, invasive plants could contribute to the development of the local economy, provide employment, and reduce poverty in several locations.

5. Given that the dam is a protected area, harvesting activities should be regulated such that reintroduction of aquatic invasive plants (AIPS) or their cultivation anywhere else due to their economic benefits is prohibited.

6. Also only professionally trained "water workers" of the Ghana Water Company Limited (GWCL) should handle the harvesting of the invasive plants for users to prevent occupational injuries.

7. Further studies should focus on the quantification of the bioresource potential and analysis of implementation strategies for utilizing the invasive plant species. 


\section{ACKNOWLEDGMENTS}

The authors acknowledge the Water Workers at the Owabi Dam who assisted in the data collection process and Dr. Alexander K. Anning of KNUST who assisted in the identification of the invasive plants. The authors also thank the Kwame Nkrumah University of Science and Technology (KNUST) and the Ministry of Foreign Affairs of Denmark (DANIDA), DFC Project Building Stronger Universities Programme Phase III (BSU III KNUST) for providing funds for this research.

\section{REFERENCES CITED}

Aboohanah, M., and Yeaser, A. (2018). "Using the common hornwort Ceratophyllum demersum L. plant extract as a liquid fertilizer," in: Proceedings of the International Conference on Promotion of Scientific and Regional Cooperation on Food and Agricultural Sciences, Mashhad, Iran, pp. 1-2.

Abu, T. A. (2015). “A review: Aquatic macrophyte Ceratophyllum demersum L. (Ceratophyllaceae): Plant profile, phytochemistry and medicinal properties," International Journal of Science and Research 6(7), 394-399. DOI: 10.21275/art20174667

Addo-Fordjour, P., Yeboah-Gyan, K., Lawson, B. W. L., and Akanwariwiak, W. G. (2007). "Diversity and distribution of ferns on the campus of the Kwame Nkrumah University of Science and Technology (KNUST), Kumasi, Ghana," Journal of Science and Technology (Ghana) 27(1), 35-44. DOI: 10.4314/just.v27i1.33022

Atala, A. (2012). "A new ingredient: The introduction of priprioca in gastronomy," International Journal of Gastronomy and Food Science 1(1), 61-81. DOI: 10.1016/j.ijgfs.2011.11.001

Bansal, S., Lishawa, S. C., Newman, S., Tangen, B. A., Wilcox, D., Albert, D., Anteau, M. J., Chimney, M. J., Cressey, R. L., and DeKeyser, E., et al. (2019). "Typha (cattail) invasion in North American wetlands: Biology, regional problems, impacts, ecosystem services, and management," Wetlands 39(4), 645-684. DOI: 10.1007/s13157-019-01174-7

Bidin, N., Zakaria, M. H., Bujang, J. S., and Aziz, N. A. A. (2015). "Suitability of aquatic plant fibers for handmade papermaking," International Journal of Polymer Science 2015(1), Article ID 165868. DOI: 10.1155/2015/165868

Boadu, A. A., and Asase, A. (2017). "Documentation of herbal medicines used for the treatment and management of human diseases by some communities in Southern Ghana," Evidence-Based Complementary and Alternative Medicine 2017, Article ID 3043061. DOI: 10.1155/2017/3043061

Borokini, T. I., and Babalola, F. D. (2012). "Management of invasive plant species in Nigeria through economic exploitation: Lessons from other countries," Management of Biological Invasions 3(1), 45-55. DOI: 10.3391/mbi.2012.3.1.05

Centre for Agriculture and Bioscience International (CABI) (2004). Invasive Species Compendium, CABI, Wallingford, England.

Chapman, D., Coetzee, J., Hill, M., Hussner, A., Netherlands, M., Newman, J., Pescott, O., Stiers, I., van Valkenburg, J., and Tanner, R. (2017). “Pistia stratiotes L.," EPPO Bulletin 47(3), 537-543. DOI: 10.1111/epp.12429 
Chopra, R. N., Nayar, S. L. and Chopra, I. C. (1986). Glossary of Indian Medicinal Plants, Council of Scientific and Industrial Research, New Delhi, India.

Colbers, B., Cornelis, S., Geraets, E., Gutiérrez-Valdés, N., Tran, L. M., MorenoGiménez, E., and Ramírez-Gaona, M. (2017). A Feasibility Study on the Usage of Cattail (Typha spp.) for the Production of Insulation Materials and Bio-adhesives, Wageningen University and Research Centre, Wageningen, Netherlands.

Comedis, E., Ayran, J., Camacho, J. S. L. J., De Leon, J. A., and Segura, R. I. I. (2017). "Modern eco-friendly containers: Transforming water lilies into proactive environmental product," in: Proceedings of the DLSU Research Congress 2017, De La Salle University, Manila, Philippines, pp. 1-7.

Cusick, A. W., and Ortt, M. (1987). "Polygonum perfoliatum L. (Polygonaceae): A significant new weed in the Mississippi drainage," SIDA, Contributions to Botany 12(1), 246-249.

Dogan, M., Emsen, B., Aasim, M., and Yildirim, E. (2017). "Ceratophyllum demersum L. extract as a botanical insecticide for controlling the Maize Weevil, Sitophilus zeamais Motschulsky (Coleoptera: Curculionidae)," Egyptian Journal of Biological Pest Control 27(1), 11-15.

Dos Santos, L. L., Do Nascimento, A. L. B., Vieira, F. J., Da Silva, V. A., Voeks, R., and De Albuquerque, U. P. (2014). "The cultural value of invasive species: A case study from semi-arid Northeastern Brazil," Economic Botany 68(3), 283-300. DOI: 10.1007/s12231-014-9281-8

Dubbe, D. R., Garver, E. G., and Pratt, D. C. (1988). "Production of cattail (Typha spp.) biomass in Minnesota, USA," Biomass 17(2), 79-104. DOI: 10.1016/01444565(88)90073-X

Duke, J. A., and Ayensu, E. S. (1985). Medicinal Plants of China (Volume 2), Reference Publications, Texas, United States.

Ekunseitan, D. A., Yusuf, A. O., and Odesanmi A. F. (2013). "Assessment of nutritive values of some waterweeds," Food Science and Quality Management 22, 23-28.

Emboden, W. A. (1981). "Transcultural use of narcotic water lilies in ancient Egyptian and Maya drug ritual," Journal of Ethnopharmacology 3(1), 39-83. DOI: 10.1016/0378-8741(81)90013-1

Eminniyaz, A., Qiu, J., Tan, D., Baskin, C. C., Baskin, J. M., and Nowak, R. S. (2013). "Dispersal mechanisms of the invasive alien plant species Buffalobur (Solanum rostratum) in cold desert sites of Northwest China," Weed Science 61(4), 557-563. DOI: 10.1614/WS-D-13-00011.1

Essuman, E. K. (2013). Protein Extraction from Fern and Its Physicochemical Properties, Master's Thesis, Kwame Nkrumah University of Science and Technology, Kumasi, Ghana.

Fareed, M. F., Haroon, A. M., and Rabeh, S. A. (2008). "Antimicrobial activity of some macrophytes from Lake Manzalah (Egypt)," Pakistan Journal of Biological Sciences 11(21), 2454-2463. DOI: 10.3923/pjbs.2008.2454.2463

Foroughi, M., Najafi, P., Toghiani, A., and Honarjoo, N. (2010). "Analysis of pollution removal from wastewater by Ceratophyllum demersum," African Journal of Biotechnology 9(14), 2125-2128.

Global Invasive Species Database (2020). "Species profile: Ceratophyllum demersum," (http://www.iucngisd.org/gisd/species.php?sc=281), Accessed 13 Feb 2020. 
Grosshans, R. (2014). Cattail (Typha Spp.) Biomass Harvesting for Nutrient Capture and Sustainable Bioenergy for Integrated Watershed Management, Doctoral Dissertation, University of Manitoba, Manitoba, Canada.

Havel, J. E., Kovalenko, K. E., Thomaz, S. M., Amalfitano, S., and Kats, L. B. (2015). "Aquatic invasive species: Challenges for the future," Hydrobiologia 750(1), 147170.

Huth, W. L., McEvoy, D. M., and Morgan, O. A. (2018). "Controlling an invasive species through consumption: The case of lionfish as an impure public good," Ecological Economics 149(C), 74-79. DOI: 10.1016/j.ecolecon.2018.02.019

Huxley, A. J., and Griffiths, M. (1992). Dictionary of Gardening, Stockton Press, New York, USA.

Invasive Species Specialist Group (ISSG) (2006). Global Invasive Species Database (GISD). Auckland, NZ, University of Auckland, Centre for Invasive Species Research, 2006

Islam, F., Hossain, A., Hossain, M. G., Murshid, G. M. M., and Rahman, M. M. (2015). "Evaluation of antioxidant, analgesic and cytotoxic activities of Typha angustata L. root," Dhaka University Journal of Pharmaceutical Sciences 14(1), 55-59. DOI: 10.3329/dujps.v14i1.23736

Ito, E. E., Nmor, J. C., Ake, J. E. G., and Utebor, K. (2015). "Larvicidal activity of Pistia stratiotes (water lettuce) against larvae of Aedes aegypti," Advances in Research 3(6), 589-595. DOI: 10.9734/AIR/2014/13667

Jahan, M. S., Islam, M. K., Chowdhury, D. A. N., Moeiz, S. M. I., and Arman, U. (2007). "Pulping and papermaking properties of pati (Typha)," Industrial Crops and Products 26(3), 259-264. DOI: 10.1016/j.indcrop.2007.03.014

Jayasuriya, M. (2011). "Our national flower may soon be a thing of the past," The Sunday Times April 17, 2011

Jomjun, N., Siripen, T., Maliwan, S., Jintapat, N., Prasak, T., Somporn, C., and Petch, P. (2010). "Phytoremediation of arsenic in submerged soil by wetland plants," International Journal of Phytoremediation 13(1), 35-46. DOI: 10.1080/15226511003671320

Jones, M. B., Kansiime, F., and Saunders, M. J. (2018). "The potential use of papyrus (Cyperus papyrus L.) wetlands as a source of biomass energy for sub-Saharan Africa," GCB Bioenergy 10(1), 4-11. DOI: 10.1111/gcbb.12392

Kakarla, L., Allu, P. R., Rama, C., and Botlagunta, M. (2014). "A review on biological and chemical properties of Cyperus species," Research Journal of Pharmaceutical, Biological and Chemical Sciences 5(4), 1142-1155.

Kanwal, S., Iram, S., Khan, M., and Ahmad, I. (2011). "Aerobic composting of water lettuce for preparation of phosphorus enriched organic manure," African Journal of Microbiology Research 5(14), 1784-1793.

Karale, S. S., Jadhav, S. A., Chougule, N. B., Awati, S. S., and Patil, A. A. (2013). "Evaluation of analgesic, antipyretic and anti-inflammatory activities of Ceratophyllum Demersum Linn. in albino rats," Current Pharma Research 3(4), 1027-1030. DOI: 10.33786/JCPR.2013.v03i04.009

Karataş, M., Aasim, M., and Doğan, M. (2014). "Multiple shoot regeneration of Ceratophyllum demersum L. on agar solidified and liquid mediums," Fresenius Environmental Bulletin 23(1), 3-9. 
Kasulo, V. (2000). "The impact of invasive species in African lakes," in: The Economics of Biological Invasions, C. Perrings (ed.), Edward Elgar, Cheltenham, United Kingdom, pp. 262-297.

Kaur, M., Kumar, M., Sachdeva, S., and Puri, S. K. (2018). "Aquatic weeds as the next generation feedstock for sustainable bioenergy production," Bioresource Technology 251, 390-402. DOI: 10.1016/j.biortech.2017.11.082

Kayabaş, N. P., Tümen, G., and Polat, R. (2018). "Wild edible plants and their traditional use in the human nutrition in Manyas (Turkey)," Indian Journal of Traditional Knowledge 17(2), 299-306.

Keskinkan, O., Goksu, M. Z. L., Basibuyuk, M., and Forster, C. F. (2004). "Heavy metal adsorption properties of a submerged aquatic plant (Ceratophyllum demersum)," Bioresource Technology 92(2), 197-200. DOI: 10.1016/j.biortech.2003.07.011

Khan, M. A., Marwat, K. B., Gul, B., Wahid, F., Khan, H., and Hashim, S. (2014). "Pistia stratiotes L. (Araceae): Phytochemistry, use in medicines, phytoremediation, biogas and management options," Pakistan Journal of Botany 46(3), 851-860.

Khare, C. P. (2004). Indian Herbal Remedies: Rational Western Therapy, Ayurvedic, and Other Traditional Usage, Botany, Springer Science \& Business Media, Berlin, Germany.

Koranteng, S. S., Darko, D. A., Nukpezah, D., and Ameka, G. K. (2018). "Pesticides bioconcentration potential of aquatic plants in the Volta lake," West African Journal of Applied Ecology 26(SI), 193-202.

Kumar, H. S., Raju, M. B. V., Dinda, S. C., Sahu, S. K., and Banerjee, M. (2011). "Analgesic, anti-inflammatory and antipyretic activity of Pistia stratiotes L.," Rasayan Journal of Chemistry 4(3), 506-511.

Kusolsongtawee, T., Wuttilerts, T., Chulalaksananukul, S., and Maneechot, L. (2018). "Bioethanol production from Ceratophyllum demersum L. and carbon footprint evaluation," Applied Science and Engineering Progress 11(2), 103-108. DOI: 10.14416/j.ijast.2018.04.002

Langeland, K., Netherland, M., Haller, W., and Koschnick, T. (2006). Efficacy of Herbicide Active Ingredients Against Aquatic Weeds 1. Biology and Control of Algae (Document No. SS AGR 44), Agronomy Department, University of Florida, Gainesville, USA.

Leach, B., and Tait, I. (2000). "Papyrus," in: Ancient Egyptian Materials and Technology, Cambridge University Press, Cambridge, United Kingdom. pp.227- 253.

Leger, E. A., and Espeland, E. K. (2010). Perspective: Coevolution between native and invasive plant competitors: Implications for invasive species management," Evolutionary Applications 3(2), 169-178.

Lim, T. K. (2016). "Zingiber officinale," in: Edible Medicinal and Non-Medicinal Plants, Springer, Cham, Switzerland, pp. 469-560.

Liu, Z., Lu, B., He, B., Li, X., and Wang, L. A. (2019). "Effect of the pyrolysis duration and the addition of zeolite powder on the leaching toxicity of copper and cadmium in biochar produced from four different aquatic plants," Ecotoxicology and Environmental Safety 183, Article ID 109517. DOI: 10.1016/j.ecoenv.2019.109517

Łuczaj, Ł. (2008). "Archival data on wild food plants used in Poland in 1948," Journal of Ethnobiology and Ethnomedicine 4(1), Article number 4. DOI:10.1186/1746-4269-4-4

Ma, J., Ugya, Y. A., Isiyaku, A. U., Hua, X., and Imam, T. S. (2019). "Evaluation of Pistia stratiotes fractions as effective larvicide against Anopheles mosquitoes," 
Artificial Cells, Nanomedicine, and Biotechnology 47(1), 945-950. DOI:

10.1080/21691401.2019.1582538

Maema, L. P., Potgieter, M., and Mahlo, S. M. (2016). "Invasive alien plant species used for the treatment of various diseases in Limpopo Province, South Africa," African Journal of Traditional, Complementary and Alternative Medicines 13(4), 223-231. DOI: 10.21010/ajtcam.v13i4.29

Maha, M., Rajendran, A., and Das, J. (2014). "Genetic diversity and relationships of selected Polygonum species using RAPD analysis," Research in Plant Biology 4(2), $1-8$.

Malathy, R., and Stanley, S. A. (2015). "Studies on the potential therapeutic effects on the aquatic macrophytes namely Cabomba aquatica, Ceratophyllum demersum, and Hygrophila corymbose," Journal of Chemical and Pharmaceutical Research 7(4), 479-483.

Manfredi, E. C., Flury, B., Viviano, G., Thakuri, S., Khanal, S. N., Jha, P. K., Maskey, R. K., Kayastha, R. B., Kafle, K. R., Bhochhibhoya, S., et al. (2010). "Solid waste and water quality management models for Sagarmatha National Park and Buffer Zone, Nepal," Mountain Research and Development 30(2), 127-142. DOI: 10.1659/MRDJOURNAL-D-10-00028.1

Mburu, N., Rousseau, D. P., Van Bruggen, J. J., and Lens, P. N. (2015). "Use of the macrophyte Cyperus papyrus in wastewater treatment," in: The Role of Natural and Constructed Wetlands in Nutrient Cycling and Retention on the Landscape, Springer, Cham, Switzerland, pp. 293-314.

McCormick, F. H., Contreras, G. C., and Johnson, S. L. (2009). "Effects of nonindigenous invasive species on water quality and quantity," in: A Dynamic Invasive Species Research Vision: Opportunities and Priorities 2009-29, M. E. Dix and B. Kerry (eds.), U. S. Department of Agricultural Forest Products Laboratory, Madison, WI, USA, pp. 111-120.

McPherson, A., and McPherson, S. (1977). Wild Food Plants of Indiana and Adjacent States, Indiana University Press, Bloomington, United States.

Moerman, D. (2010). Native American Food Plants: An Ethnobotanical Dictionary, Timber Press, Portland, United States.

Mohammed, H. A., Uka, U. N., and Brini-Yauri, Y. A. (2015). "Evaluation of nutritional composition of waterlily (Nymphaea lotus Linn) from Tatabu-Flood Plain, north central Nigeria," Journal of Fisheries and Aquatic Science 8(1), 261-264. DOI: 10.3923/jfas.2013.261.264

Morrison, E. H. J., Banzaert, A., Upton, C., Pacini, N., Pokorný, J., and Harper, D. M. (2014). "Biomass briquettes: A novel incentive for managing papyrus wetlands sustainably?," Wetlands Ecology and Management 22(2), 129-141. DOI: 10.1007/s11273-013-9310-x

MPI Biosecurity New Zealand (2012). Biosecurity Response Knowledge Base. New Zealand Government, Wellington, New Zealand.

Muniappan, R., Reddy, G. V., and Raman, A. (2009). Biological Control of Tropical Weeds Using Arthropods, Cambridge University Press, Cambridge, England.

National Institute of Water and Atmospheric Research (NIWA) (2005). "Website title," (http://www.niwa.cri.nz), Accessed 04 Oct 2019.

Nipaney, P. C., and Panholzer, M. B. (1987). "Influence of temperature on biogas production from Pistia stratiotes,” Biological Wastes 19(4), 267-274. 
Northey, A. (2014). "Pacific northwest invasive species," (https://depts.washington.edu/oldenlab/wordpress/wp-content/uploads/2015/ 09/Nymphaea_odorata_Northey_2014.pdf), Accessed 12 Nov 2019.

Oladimeji, H. O., Ubulom, P. M., Akpabio, E. I., Etim, I. E., and Nyong, E. (2008). "Larvicidal and anti-microbial potentials of Nymphaea odorata," J Pharmacol Toxicol 3(5), 357-362. DOI: 10.3923/jpt.2008.357.362

Ortiz, S., Carbajal, R., and Serrano, M. (2008). "A new species of Polygonum L. (Polygonaceae) from South Africa," Botanical Journal of the Linnean Society 157(1), 111-114. DOI: 10.1111/j.1095-8339.2007.00768.x

Pastare, L., Romagnoli, F., Rugele, K., Dzene, I., and Blumberga, D. (2015). "Biochemical methane potential from anaerobic digestion of the macrophyte Cerathophyllum demersum: A batch test study for Latvian conditions," Energy Procedia 72, 310-316. DOI: 10.1016/j.egypro.2015.06.045

Perrings, C., Dehnen-Schmutz, K., Touza, J., and Williamson, M. (2005). "How to manage biological invasions under globalization," Trends in ecology \& evolution 20(5), 212-215.DOI:10.1016/j.tree.2005.02.011

Polechońska, L., Klink, A., Dambiec, M., and Rudecki, A. (2018). "Evaluation of Ceratophyllum demersum as the accumulative bioindicator for trace metals," Ecological Indicators 93, 274-281. DOI: 10.1016/j.ecolind.2018.05.020

Polthanee, A., Kumla, N., and Simma, B. (2015). "Effect of Pistia stratiotes, cattle manure and wood vinegar (pyroligneous acid) application on growth and yield of organic rainfed rice," Paddy and Water Environment 13(4), 337-342. DOI: 10.1007/s10333-014-0453-Z

Premkumar, V. G., and Shyamsundar, D. (2005). "Antidermatophytic activity of Pistia stratiotes," Indian Journal of Pharmacology 37(2), 127-128. DOI: 10.4103/02537613.15116

Quesada-Romero, L., Fernández-Galleguillos, C., Bergmann, J., Bravo, M. A., and Fuentes-Contreras, E. (2017). "Antifeedant and insecticidal activity of Polygonum persicaria extracts on Nomophila indistinctalis," Journal of Pharmacy \& Pharmacognosy Research 5(3), 167-173.

Rashmi, S., and Rajkumar, H. G. (2011). "Preliminary phytochemical analysis and in vitro evaluation of antifungal activity of five invasive plant species against Macrophomina phaseolina (Tassi) Goid," International Journal of Plant Research 1(1), 11-15. DOI: 10.5923/j.plant.20110101.02

Reed, E., and Marsh, L. C. (1955). "The cattail potential," Chemurgic Digest 14(9), 18.

Robinson, L. (1991). Field Guide to the Native Plants of Sydney, Kangaroo Press, Nashville, United States.

Ruffo, C. K., Birnie, A., and Tengnäs, B. (2002). Edible Wild Plants of Tanzania (Volume 27), Nairobi: Regional Land Management Unit/Sida, Nairobi, Kenya.

Rusnam, E. (2016). "The ability of water plants to reduce the level of mercury pollution in water quality in irrigation," International Journal of Waste Resources 6(2), Article ID 1000225.

Saha, A., Chowdhury, K. K., Bachar, S. C., Roy, S. C., and Kundu, J. K. (2005). "Antiinflammatory, analgesic, and diuretic activity of Polygonum lanatum Roxb," Pakistan Journal of Pharmaceutical Sciences 18(4), 13-18. PMID: 16380352

Selvakumari, E., Shantha, A., Kumar, C. S., and Prabhu, T. P. (2016). "Phytochemistry and pharmacology of the genus Nymphaea," Journal of Academia and Industrial Research 5 (7), 98-108. 
Singh, M., and Jain, A. P. (2017). "A review on genus Nymphaea: Multi-potential medicinal plant," Asian Journal of Pharmaceutical Education and Research 6(4), 19. DOI: $10.22270 /$ jddt.v8i6-s.2095

Smith, M. D., and Knapp, A. K. (2001). "Physiological and morphological traits of exotic, invasive exotic, and native plant species in tallgrass prairie," International Journal of Plant Sciences 162(4), 785-792. DOI: 10.1086/320774

Stephen, E. C., Adebisi, A. K., Chinedu, I., and Samuel, A. A. (2017). "Chemical composition of water lily (Nymphaea lotus) bulbs," American Journal of Food Science and Nutrition 4(2), 7-12.

Stevens, W. D., Ulloa, C., Pool, A., and Montiel, O. M. (2001). Flora de Nicaragua (Volume 85), Missouri Botanical Garden Press, St. Loui, MO, USA.

Stilinović, B., and Hrenović, J. (2000). "Nutrient removal from leachate of the Zagreb landfill Jakusevec," Acta Botanica Croatica 59(1), 215-223.

Stratton, L. C., and Goldstein, G. (2001). "Carbon uptake, growth and resource-use efficiency in one invasive and six native Hawaiian dry forest tree species," Tree Physiology 21(18), 1327-1334. DOI: 10.1093/treephys/21.18.1327

Syed, I., Fatima, H., Mohammed, A., and Siddiqui, M. A. (2018). "Ceratophyllum demersum a free-floating aquatic plant: A review," Indian Journal of Pharmaceutical and Biological Research 6(2), 10-17.

Taranhalli, A. D., Kadam, A. M., Karale, S. S., and Warke, Y. B. (2011). "Evaluation of antidiarrhoeal and wound healing potentials of Ceratophyllum demersum Linn. whole plant in rats," Latin American Journal of Pharmacy 30(2), 297-303.

Tardivel, N. (2018). Commercial Market Potentials of Invasive Alien Species in the Pacific Island Countries and Territories (PICTs) (Project No. RESCUE), Pacific Community, Suva, Fiji.

Tasmanian Weed Management Act (1999). "An Act to provide for the control and eradication of declared weeds and to promote a strategic and sustainable approach to weed management," Tasmania, Australia.

Thomaz, S. M., Kovalenko, K. E., Havel, J. E., and Kats, L. B. (2015). “Aquatic invasive species: General trends in the literature and introduction to the special issue," Hydrobiologia 746(1), 1-12. DOI: 10.1007/s10750-014-2150-8

Tobin, P. C. (2018). “Managing invasive species," F1000Research 7, 1-8. DOI: 10.12688/f1000research.15414.1

Tresidder, J. (1997). The Hutchinson Dictionary of Symbols, Duncan Baird Publishers, London, England.

Turpie, J. (2004). "The role of resource economics in the control of invasive alien plants in South Africa: Working for water," South African Journal of Science 100(1), 87-93.

UF/IFAS Center for Aquatic and Invasive Plants (2018). "Plant Directory". (http://plants.ifas.ufl.edu/plant-directory/), Accessed 12 Feb 2020

UN General Assembly (2015), Transforming our world: The 2030 Agenda for Sustainable Development, 21 October 2015, A/RES/70/1, (https://www.refworld.org/docid/57b6e3e44.html) Accessed 4 Jun 2020]

USDA PLANTS (2011). "Database on C. demersum," (https://plants.usda.gov/core/profile?symbol=CEDE4), Accessed 20 Oct 2019.

Van Meerbeek, K., Appels, L., Dewil, R., Calmeyn, A., Lemmens, P., Muys, B., and Hermy, M. (2015). "Biomass of invasive plant species as a potential feedstock for bioenergy production," Biofuels, Bioproducts and Biorefining 9(3), 273-282. DOI: 10.1002/bbb.1539 
Voeste, D., Levine, L. H., Levine, H. G., and Blüm, V. (2003). "Pigment composition and concentrations within the plant (Ceratophyllum demersum L.) component of the STS-89 CEBAS Mini-Module spaceflight experiment," Advances in Space Research 31(1), 211-214. DOI: 10.1016/S0273-1177(02)00740-8

Yeung, H. C. (1995). Handbook of Chinese Herbs and Formulas, Institute of Chinese Medicine, London, United Kingdom.

Zhang, N., Huang, L., Liu, S., Wang, Y., Luo, Y., Jin, X., Guo, J., Ke, Y., Chen, J., and Yuan, X., et al. (2013). Traditional Chinese medicine: An alternative treatment option for refractory recurrent urinary tract infections," Clinical Infectious Diseases 56(9), 1355-1355. DOI: 10.1093/cid/cit029

Article submitted: May 13, 2020; Peer review completed: August 8, 2020; Revised version received and accepted: October 27, 2020; Published: March 5, 2021.

DOI: 10.15376/biores.16.2.3075-3095 